MT-DP - 2006/2

\title{
Social Security Reform in the US: \\ Lessons from Hungary
}

\author{
ANDRÁS SIMONOVITS
}




\section{Discussion papers \\ MT-DP - 2006/2}

Institute of Economics, Hungarian Academy of Sciences

KTI/IE Discussion Papers are circulated to promote discussion and provoque comments. Any references to discussion papers should clearly state that the paper is preliminary.

Materials published in this series may subject to further publication.

Social Security Reform in the US: Lessons from Hungary

András Simonovits

Institutes of Economics Hungarian Academy of Science, (also Central European University and Budapest University of Technology) simonov@econ.core.hu

ISBN 9639588717

ISSN $1785-377 \mathrm{X}$

Publisher:

Institute of Economics, Hungarian Academy of Sciences 


\title{
Social Security Reform in the US: Lessons from Hungary
}

\author{
Simonovits András
}

\begin{abstract}
The partial privatization of the US Social Security system was clearly the top economic policy priority for the new Bush administration. While many famous economists, publicists and politicians support, others reject the partial privatization of the Social Security system. The international comparisons have been quite infrequent, concentrated on few countries (Chile, Great Britain and Sweden) and left out similar reforms introduced in similar situations, like in Hungary, Poland and other ex-communist countries. In this article I try to make up for this omission and outline the lessons from the Hungarian reform, started in 1998. The conclusion is simple: such a reform is possible but does not solve the problems of social security.
\end{abstract}

JEL: H55, J26

Keywords:

Social Security, Pensions, Prefunding of pensions, United States, Hungary

\section{Acknowledgement}

I express my gratitude to Mária Augusztinovics, Peter Diamond, Róbert Gál, Thomas L. Hoffmann, Ágnes Matits, János Réti and especially John Francis,, for their direct and indirect help during the preparation of this study.

The usual disclaimer applies. The oral version of this paper was presented at the American Economic Association's Annual Meeting, Boston, MA, on January 6, 2006. 


\title{
A társadalombiztosítási rendszer reformja az Egyesült Államokban: magyar tanulságok
}

\author{
Simonovits András
}

\section{Összefoglaló}

Az amerikai tb részleges privatizálása volt az új Bush-kormányzat első számú gazdaságpolitikai célja. Számos neves közgazdász, publicista és politikus támogatja, mások elutasítják a tb részleges privatizálását. Kevés nemzetközi összehasonlítás született, azok is csak néhány országra (Chile, Nagy Britannia és Svédország) szorítkoztak, és figyelmen kívül hagytak hasonló reformokat, amelyeket hasonló körülmények között vezettek be (Magyarország, Lengyelország és más posztkommunista ország). Ebben a cikkben megkísérlem pótolni a jelzett hiányt és az 1998-ban bevezetett magyar reformból levonni a tanulságokat. A következtetés egyszerü: ilyen reform lehetséges, de nem oldja meg a tb gondjait.

\section{Tárgyszavak:}

Társadalombiztosítás, nyugdíjrendszer, a nyugdíjrendszer feltőkésítése, Egyesült Államok, Magyarország 


\section{INTRODUCTION}

The partial privatization of the US Social Security (for short, US SS) system was clearly the top economic policy priority for the new Bush administration. While many prominent economists, public commentators, and politicians support partial privatization of the SS system, others reject it with equal fervor. International comparisons have invoked countries such as Chile, Great Britain and Sweden to evaluate the US SS reform but have overlooked more relevant reforms in Hungary, Poland and other ex-communist countries (cf. Müller, 1999; Müller et al., eds., 1999 and Fultz, ed., 2002.) In this article I try to make up for this omission and outline the lessons from the Hungarian reform initiated in 1998.

Of course, no two countries are exactly alike, and the USA, moreover, is a country in a class of its own. No two pension systems are identical, either (cf. e.g. World Bank, 1994 and Holzmann and Stiglitz, eds., 2001). Nevertheless, the initial situations at the start of reform in the US and Hungary and the plans that evolved share many similarities. Concerning the initial situation and the reform plan, the US, in fact, shares more features with Hungary than with the countries with which it is frequently compared.

The essential similarities between the initial situations in Hungary and the US can be quickly summarized. Each country had, or has, a universal and progressive public pension system (i.e. redistributive from the richer to the poorer) that provides the bulk of support in old age for the bulk of the pensioners. There is a quite wide consensus that the old system sooner or later stands in need of an important reform. The essential similarities between the two reforms can be summarized with equal ease. The contribution rate to the mandatory system is fixed. In Hungary, a significant, though not dominant share was carved out for the private, funded pillar. The reform proposal in the US carries a similar provision. In both cases, the public pillar is parametrically reformed as to lower considerably the benefitcontribution ratio. Participation in the private system is semivoluntary. The transition cost that remains after the parametric reform and that arise as a result of the diversion of contributions from Pillar 1 to the new individual accounts is financed from general revenues.

There are as well important differences between the two systems and their reforms. The US system has a huge trust fund, while the Hungarian system has no such reserves. The US public system is complemented by a semi-voluntary (employer) pension system, in which about half of all American workers participate, some of whom accumulate significant savings. In Hungary, the voluntary system started only in 1993 and most of the participants have rather modest pension savings. In the US the proposed reform retains the progressivity of the current system, while the Hungarian reform is dropping it. Furthermore, the US 
parametric reform will eventually freeze the real value of even the entry pension benefits, while the continued benefits are frozen in most pension systems. In contrast, the Hungarian reform prescribes that the real value of entry pensions in Hungary keep up with wages, while the real value of continued pensions grows at half that rate.

This comparison is obviously rudimentary. The following account will provide the needed elaboration. The punch line, which I offer here rather than withhold it until the end, is: partial privatization of the social security is possible but not helpful.

The next section of the paper outlines the present state of the US SS system. Section 3 presents the President's Commission plan as of 2002; Section 4 discusses the prereform state of the Hungarian SS system; Section 5 displays the partial privatization of the Hungarian pension system; Section 6 evaluates the Hungarian reform. In Section 7, I compare the two cases and in Section 8 offer some conclusions. Those who know the US or the Hungarian system, may drop Sections 2-3 or Sections 4-6, respectively.

\section{THE US SOCIAL SECURITY SYSTEM, 2003}

There is an enormous literature on the US SS system and it would be pointless here to attempt a recapitulation. It is characteristic, however, that various authors, depending on their perspective and predisposition, view the US system as either attractive (Diamond, 2004; Diamond and Orszag, 2004 and 2005, for example) or depressing (Feldstein, 2005a, b). On the basic facts there is much greater agreement than in their evaluations. The account below follows Diamond and Orszag (2004, pp. 14-26).

Every employee pays the SS system $6.2 \%$ on the portion of his gross wage below a ceiling that rises over time. (In 2003 the ceiling was $\$ 87,000$.) The employer pays an equal amount. In principle, workers retire at the full benefit age, which was 65 years and 8 months in 2003 (and rising). Euphemistically this quantity is called normal retirement age but the bulk of the workers retires before reaching this age. The full benefit is calculated by multiplying the individual nominal gross earnings by the annual nationwide average gross wage index. The best 35 years are selected and their average, divided by 12, determines the average indexed monthly earning, the AIME. Using a piecewise linear function with slopes 0.90; 0.32 and o.15, in the intervals ( $\$ 0, \$ 606)$; $(\$ 606, \$ 3,653)$ and above $\$ 3,653$, respectively, the AIME is transformed into the primary insurance amount, or PIA. Workers cannot receive benefits before the minimal retirement age, fixed at 62. Those who claim their benefits before reaching the full benefit age have a PIA reduced according to actuarial principles. For example, a person who claims his benefit in 2003 at age 62, has a benefit 23.33\% lower than 
his PIA. Those who claim their benefit after reaching the full benefit age enjoy a credit for delayed retirement. For example, a 70-year-old who retires in 2008 will receive a monthly benefit which is $32.5 \%$ higher than the PIA. The benefits of those who already retired increase every year according to the consumer price index and are paid until death: indexed unisex life annuity.

For workers who qualify for disability benefits, the AIME is calculated over the relevant working period. As for family benefits, retirement of a spouse of a retiree who reaches age 62 without an independent SS benefit or with a benefit lower than half that of the retired spouse results in the payment to the couple of a benefit that is $150 \%$ of the higher benefit. The spouse of a deceased worker may claim a survivor's benefit, the amount depending on the age of the widow(er) and on the age of the deceased worker when he first claimed his benefit. A child under age 18 who survives a deceased worker receives 75 percent of that worker's PIA until age 18. (There are some limits on these benefits.) The SS benefits are partially taxed and the tax revenue flows to the SS and Medicare Trust Funds.

Before turning to the future of the US SS system, we should note the role of SS in old-age security. "[SS] represents 90 percent or more of total income for almost one-third of elderly beneficiaries. .... [SS] benefits account for more than half of total income for almost twothirds of beneficiaries over age 65." (Diamond and Orszag, 2004, p. 15). For those with large private savings and generous private pensions, SS benefits are not essential or dominant. Characteristically, the total of private pension contributions approximately equals that of SS contributions.

There is agreement among the representatives of the differing schools of thought that the US SS needs an overhaul. This agreement reflects recognition that sometime around the year 2018 the Trust Fund, in all likelihood, will cease to grow, begin to shrink, and around 2042, be exhausted. If the current rules are not changed much before 2042, then the benefits will of necessity be dramatically reduced or the payroll tax rates dramatically increased.

Diamond and Orszag $\left(2004,55^{-78}\right)$ offer three major explanations for this deficit in the balances of the SS system. The first is increasing life expectancy at age 65. Although the full benefit age is increasing, the improvement in life expectancy is faster than planned, thus creating a deficit while actuarial adjustment prevents further reductions. The second explanation is increasing earnings inequality. Though the SS contribution has an indexed ceiling, the increasing average real earnings and especially the increasing earnings inequality has raised the share in national income of aggregate earnings above the ceiling, from about $10 \%$ in 1983 to $17 \%$ in 2000 . The first and the second causes interact: the improvement in life expectancy is much faster among the rich than among the poor even for the older population but less sharply than for the younger population. The third factor is the existence 
of the legacy debt, defined as the present value of the benefits less the present value of the contributions of the early beneficiaries (born before 1936). Its current value in 2002 dollars is about 12 trillion dollars and must be financed by later beneficiaries (born since 1936).

Something needs to be done to claw back some of the pension promises. This is called pension reform. There are, however, many ways to effect pension reform and decades will pass before we can know whether the path chosen was the right one.

There is the "tune it up, don't trade it in" approach of economists (Aaron and Reischauer, 2001 and Diamond and Orszag, 2004, for example) who are convinced that so-called parametric reform of the SS system is sufficient to save it. The basic idea of Diamond and Orszag (2004), for example, is to reduce the benefit dynamic while increasing the contribution rate and increase normal retirement age even faster than prescribed in the actual law, splitting the burden of adjustment between relative benefit reduction and an increase in contributions. In addition, they propose some further improvement in the social insurance function of the SS system, but its outline is beyond the scope of the present paper.

Proponents of privatization (e.g., Kotlikoff, 1997; Feldstein and Samwick, 2002; and Feldstein, 2005a, b) do not accept that any parametric reform is sufficient or suitable for strengthening the old-age insurance system. As is known, already in his first presidency, George W. Bush appointed a committee (the President's Commission, 2002) charged with the outlining a reform of the SS system through partial privatization. As the reelected president, Bush immediately announced that he pushes his original plan.

Before closing this Section, I would like to make three remarks on life-cycle issues in the US:

a) One cannot expect that poor workers will happily contribute to pension funds that earn interest rates of $9 \%$ per year while paying twice that in interest charges on credit card debt (e.g., Gill et al., 2005). It would be much more helpful to convince and help these persons to use much less these expensive credits that will leave them sufficient savings at retirement.

b) The sustained, rapid growth of US housing prices makes it possible for even the richer groups of the US workers to finance excessive consumption through home equity loans. If personal private saving is financed from such a source, then the introduction of private pension accounts does not increase total savings (Vittas, 1997). Note that the repayment of this type of loans enjoys tax relief, achieving perverse income redistribution from the poor to the rich.

c) If the US government is concerned by the growing future public burden, the simplest thing would be to slow the spectacular rise of the US foreign debt. 


\section{THE PRESIDENT'S COMMISSION PLAN}

Of course, the situation of the US economy in 2005 is rather different from that in 2002, when the President's Commission published its plans and additional time will be needed to legislate such a long-term reform. Nevertheless, we have no better choice than to refer to the 2002 plan.

In 2001, President Bush put forward six principles to which the Committee should adhere:

1. "Modernization must not change benefits of [current] retirees and near retirees."

2. "The entire Social Security surplus must be dedicated to Social Security only."

3. "The Social Security payroll tax rate must not be increased."

4. "Government must not invest Social Security funds in the stock market."

5. "Modernization must preserve Social Security disability and survivors' components."

6. "Modernization must include individually controlled, voluntary personal retirement accounts, which augment the Social Security safety net."

The President's Committee presented three plans but we shall deal only with the second, considered the most relevant. The basic idea is to carve out $4 \%$ of gross wage, i.e. about $1 / 3$ of total contributions up to an annual maximum $\$ 1,000$ and put it to an individual account. To preserve the progressivity of the combined system and assure that participation is advantageous, a complex mechanism would connect the reduction of the SS benefit with the fresh individual one at retirement. To save on menacing operating costs (Murthi et al., 2001), an individual account will not be individually managed until its assets reach a significant sum, say $\$ 5,000$, where the relative operating costs cease to be unbearable. To enhance the appeal of the combined system, the assets held in individual accounts can be inherited by the survivors until the owner's retirement. The obscure gimmick in the reform is the introduction of indexing the AIME to reflect changes in prices rather than wages, a change that would yield savings to the remaining SS pillar by drastically reducing the replacement and contribution rates.

In order to clarify the differences between the two approaches, I present a simplified comparison between the two plans. As Diamond and Orszag note, the private benefit of the combined system is much riskier than the public part. Moreover, there is no agreement among economists as to how to take this difference into account. At the extremes, it is possible to ignore the difference between risks or fully take them into account. The reality lies possibly much closer to the second than to the first option. 
Table 1.

\section{Changes in Benefits for Average-Earning Two-Earner Couples: Diamond- Orszag's Proposal and President's Commission Model 2: percent change from scheduled benefits}

\begin{tabular}{|l|l|l|l|l|}
\hline $\begin{array}{l}\text { Year turning } \\
\text { age 65 }\end{array}$ & $\begin{array}{l}\text { Diamond- } \\
\text { Orszag's plan }\end{array}$ & $\begin{array}{l}\text { Model 2 } \\
\text { traditional }\end{array}$ & $\begin{array}{l}\text { Model 2 } \\
\text { combined: } \\
\text { not adjusted } \\
\text { for risk }\end{array}$ & $\begin{array}{l}\text { Model 2 } \\
\text { combined: } \\
\text { adjusted } \\
\text { for risk }\end{array}$ \\
\hline 2012 & -0.0 & -0.9 & 0.0 & -0.5 \\
\hline 2022 & -0.6 & -9.9 & -6.1 & -8.5 \\
\hline 2032 & -3.7 & -18.2 & -8.3 & -15.2 \\
\hline 2042 & -7.8 & -25.7 & -5.9 & -20.5 \\
\hline 2052 & -11.7 & -32.5 & -6.3 & -26.1 \\
\hline 2075 & -19.7 & -45.9 & -20.5 & -39.6 \\
\hline
\end{tabular}

Source: Diamond and Orszag (2003), Table F-2, p. 222.

By way of illustration, the last row of Table 1 shows the benefits of those who turn 65 in 2075. According to the Diamond-Orszag plan, they would lose about 20\% with respect to the present, unsustainable system. According to the President's Commission plan, those remaining in the traditional system, would lose $46 \%$. For those who join the combined system, the loss will be 20 or $40 \%$, depending on whether the risk in the private benefit is taken into account. It is worth mentioning that even in the optimistic (first) case, the loss is equal to that in the Diamond-Orszag plan (though without paying an increased payroll tax rate) and in the pessimistic and more realistic (second) case, the loss is double.

There are serious problems with the President's Commission plan. Most importantly,

1. It would significantly reduce the replacement rate of the remaining SS component.

2. With inheritability of the individual accounts many elderly will receive lower benefits than without, since the assets passed on as an inheritance will be lost to the pension system

3. Personal, individually managed accounts carry considerable risk and are not insured against the worst outcomes.

Some economists, it should be noted, who favor privatization but still consider it important to separate parametric and structural reform, propose a hybrid indexation of the 
public entry benefits rather than eventual freezing. This reform would preserve indexation in accordance with wages for those workers with the lowest earnings. (Cf. for example, Scheiber and Shoven in Posen et al., 2004.) It is of certain interest that another group of the proponents of privatization (Feldstein and Kotlikoff) also favor a (temporary) increase in the mandatory contribution rate.

\section{THE HUNGARIAN SOCIAL SECURITY UNTIL 1998}

Since there are strong differences of opinion concerning the impact of SS privatization, it may be helpful to look at a comparable reform of a similar system, not so much that of Chile, Great Britain or Sweden, but of Hungary in 1998. In the next three Sections we shall discuss the Hungarian SS system before, during, and after the reform. Since my only objective is to contribute to the evaluation of the proposed US SS reform, I will skip details that have no relevance to the comparison. (For details on the Hungarian case, see Augusztinovics and Martos (1995), Palacios and Rocha (1998), Augusztinovics (1999), Simonovits (2001), Augusztinovics et al. (2002), Rocha and Vittas (2002) and Gál and Tarcali (2003).)

Hungary is a middle-sized and middle-income country of some 10 million inhabitants with PPP per-capita GDP of about $56 \%$ of the EU-15 average in 2002. By now, the bulk of the economy has been privatized and after reaching the trough of the transformational depression in 1993, has been developing significantly more rapidly than the EU-15. In May 2004, Hungary joined the EU with 9 other countries, mostly excommunist ones.

Hungary is an aging country, with low fertility and relatively high age-specific adult mortality rates. As a result, the old-age demographic dependency rate was about $40 \%$ in 1994 and is expected to rise to $52 \%$ by 2030 , not dramatic, particularly when one takes account of the low full benefit ages of 1994, namely 55 for women and 60 for men.

During the communist era, Hungary had built up a generous SS system, which was universal and which was combined with a similar, publicly provided health system (cf. Bokros and Dethier, eds. 1998). By 1990, the ratio of public pension expenditures to GDP reached $10 \%$ and has remained around this value. (This is about twice the corresponding US value but only about two-thirds of that of Poland or Italy.) As an important legacy of the communist approach, the public pension system was highly progressive: higher earnings and longer employment increased the entry benefits (PIA) much less than proportionally and due to insufficient indexation of higher benefits, the dispersion of the benefits in progress diminished with the time elapsing from retirement. 
During the privatization of the economy, the employment rate (for age-group 15-64 year) dropped drastically (from $76 \%$ in 1989 to $60 \%$ in 1993) and has barely increased since. This change hit the pension system from two sides: various groups in the labor force chose early retirement, particularly the unemployed and those working in the hidden economy, significantly increasing the number of the pensioners while reducing the number of contributors. A simple consequence of this process was the surge in the so-called system dependency ratio, that is, the ratio of the number of pensioners to the number of workers, from $51 \%$ to $84 \%$. (Warning: this number contains not only proper old-age pensioners but survivor and disability beneficiaries as well.) The consequence was direct: the payroll tax rates had to be raised and benefit rates had to be cut.

The transition from socialism to capitalism was accompanied by a significant drop in real earnings. In 1992, the appearance of two-digit inflation made the application of wage indexation of pension benefits inevitable. While the indexation of pensions more or less ensured the relative income position of pensioners with respect to workers, the progressive benefit formula of the new pensions gave rise to widespread underreporting of earnings and shorter episodes of contribution. Without going into details, let us emphasize that the Hungarian benefit rule is similar to but more cumbersome than the US one. The entry benefit (age-adjusted PIA, to be paid to those retired in the given year) is the product of two quantities: the reference wage and the index of the number of years of employment, called scale. The reference wage is a progressive function of average indexed wages between 1988 and the year of retirement (an abbreviated version of the US AIME). The scale was also a strongly progressive function of the number of years: it started at $33 \%$ after 10 years of employment and reached $75 \%$ after 40 years, increasing by 2 , then by $1 \%$, and finally by $0.5 \%$ per year of additional employment.

By 1995, a consensus had emerged: the Hungarian pension system needed reform. As in the US today, there were two camps in Hungary: (1) those who wanted to keep a pure public pension system by introducing parametric reforms (e.g., Augusztinovics and Martos, 1995) and (2) those who wanted to replace at least a large part of the public system with a private (and funded) pillar (e.g. Palacios and Rocha, 1998). The former were convinced that the parametric reforms of the SS system not only necessary but also sufficient. Following the ideas of the World Bank (1994), the latter did not accept the sufficiency of such reforms. Moderate privatizers considered that partial privatization was necessary to hide the parametric reforms from the public, while radical privatizers believed in the superiority of any private system over any public one, including pensions, education, health care and transportation. (Various transition scenarios are modeled and compared in Simonovits, 2003, Chapter 15.) 
In 1997, Hungary chose the second route to reform: partial privatization. Since then, except for the two richest countries, Slovenia and the Czech Republic, the bulk of the countries in the regions have followed suit.

\section{THE HUNGARIAN PENSION REFORM: 1998}

Here I will elaborate the compressed account of the Hungarian pension reform offered in the Introduction. The law adopting private individual accounts was passed by Parliament in the summer of 1997 and went into effect on January 1, 1998. Consider first the parametric reforms and then the systemic ones.

\section{PARAMETRIC REFORMS}

By definition, the parametric reforms were confined to the public pillar.

The simplest element of the parametric reform has been the fast increase in 1997 of the full benefit age from 60 to 62 years for men, and for women, progressively from 55 to age 62 by 2009. As in the US, the entry benefit of those who delay retirement beyond the full benefit age, is raised significantly. Those who retire before reaching the full benefit age experience a significant reduction. (I note in passing that the rules of transition are so generous that the bulk of retirees still retires much in advance of the full benefit age.)

Since 1998, the progressivity of the entry benefit formula has been steadily diminishing. On the one hand, the bend points of the reference wage-earning formula have been increasing much more rapidly than prices, thus phasing out this type of progressivity. On the other hand, since 1997, the last increment of the scale, the so-called accrual rate was raised from 0.5 to $1.5 \%$, lifting the foregoing scale from $75 \%$ to $80 \%$ after 40 years of service.

Currently, the already paid benefits are increased on the basis of combined wage-price indexation which in 2000 replaced indexation based on wages alone. Since the initiation of the reform measures, as wages have been increasing much more rapidly than prices, technical measures have significantly reduced relative pension dynamics. (I note, again in passing, that successive governments made important and inconsistent changes in the key parameters of the system: reducing the mandatory contribution rates and increasing the benefit-contribution ratios, see Gál and Tarcali, 2003, for example.)

The final state of this evolving system will include a proportional entry benefit, gross rather than net, with a uniform accrual of $1.65 \%$. After 40 years of employment, the resulting pretax entry benefit will be $66 \%$ of the reference gross wage. 


\section{SYSTEMIC REFORMS}

From the point of view of our paper, the systemic reforms are more spectacular than the parametric reforms. In 1998, Hungary, a pioneer among the excommunist countries in this regard, partially privatized its SS system. Rather than adding a new pillar on the top of the old SS system, the government carved out a mandatory private pillar from the old system. For the members of the combined system, roughly one-quarter (8\%) of the total mandatory contribution was to be channeled into the private pillar while roughly three-quarters (23\%) was directed to the public pillar.

Initially, there were numerous pension funds. Rapidly, however, the bulk of both capital and membership became concentrated in the six biggest firms, each connected with large financial institutions - banks or insurance companies. The workers are free to join any pension fund and to switch funds at any time. The funds are required to offer a range of portfolios, from conservative to aggressive growth funds.

As the private pillar is mandatory, the government monitors the operation of the private funds: its supervisory board ensures that the funds follow rules. Moreover, originally there was a government guaranty behind them that limited members' loss to $7 \%$ of the traditional public benefit. With time, this guarantee was discreetly withdrawn.

Consistent with the mandatory character of the two-pillar system, after 15 years participation the private pillar will also pay retirees a life annuity. These annuities must be computed on the basis of unisex life expectancy tables. To make the private and the public entry benefits comparable, rather surprisingly, the law also requires wage-price indexation of private life annuities.

Rather than separate disability and survivor insurance functions from retirement security relegating it to the public domain, proportional fractions of the former were transferred into the private domain. Those who become disabled have been given the option of returning to the traditional public system. Should the disabled beneficiary die before retirement, his or her heirs can inherit the accumulated capital of the deceased.

Participation in the mixed system is mandatory for those who enter the labor market after June 30, 1998 but optional for those who paid contributions to the SS system before 1998. Assuming that the mixed system survives, it will be decades before the traditional public system disappears.

Although the reform government preached the superiority of the private system over the public one, to save on transition costs, it sought to confine participation to younger cohorts. As an automatic tool for limitation, the government framed the transition rules so that joiners lost about $1 / 4$ of their contributions to the prereform system. About half of all workers joined the mixed system during the transition period which lasted until August 31, 
1999. These were drawn predominantly from younger cohorts. According to realistic projections, a significant part of those who joined the mixed system will have lost thereby (Simonovits, 2003, Table 5.2 and Figure 9.1).

The most pressing question of such a reform is this: Who will bear the costs of transition? By design, the reduction of promises for the traditional and the first pillar benefits (parametric reform), and the voluntary chosen benefit loss of the older entrants to the mixed system achieve considerable reduction in public benefits. But these reductions do not eliminate the temporary gap that arises between current contributions and benefits. The government made a promise to finance the cost of transition from general revenues.

\section{EVALUATION OF THE HUNGARIAN REFORM}

\section{GENERAL EVALUATION}

The Hungarian pension reform has passed its seventh birthday and has already accumulated considerable experience. Here I would like to summarize aspects of that experience most relevant to US reform efforts.

Partial privatization of a mature and universal public system is possible even in middleincome countries like Hungary and other exsocialist countries. Judging by the number of voluntary joiners, such a transition can be quite popular, at least for a while. In the age of our computerized world, even small firms can direct the monthly private contributions of their workers to various funds and well-developed pension funds are able to invest these relatively small contributions (about 60 dollars/month).

At the start, it was hoped that partial privatization of the SS system would enhance compliance and draw workers back from the gray economy into the "world of labor." It is true that participation in any mandatory system strongly depends on the perceived relation between individual costs and benefits (Kotlikoff, 1997) and both pillars are much more transparent than the old system was. But it was naive to believe (if anyone actually did believe) that workers from the gray economy would suddenly report their total earnings, i.e. gross earning $\times(1+$ employer's contribution rate $)$ and pay $23 \%$ of the gross wage as the public pension system plus $15 \%$ of the gross wage as the public health system and the 20-30$40 \%$ of the gross wage as personal income taxes just to participate in the private pension fund with the modest $8 \%$ contribution! But even if the whole SS system had been privatized as in Chile, poor workers could not have afforded any contribution (Gill et al., 2005). 
I do not want to dwell on the specific mistakes of the Hungarian reform, because the US reader might think that such errors could not occur in a developed country like the US. I turn rather to general problems of relevance to the US blueprint.

1. There is an inherent contradiction between the introduction of a private pillar and the maintenance of a dominant public pillar. (How can the government expect of workers to fully contribute to an "inferior" but dominant first pillar when the government has just partially replaced it by a "superior" though dominated second pillar?)

2. Private funds, especially those based on individual rather than firm membership, have high operating costs. (During a period of spectacular economic growth, in 1998-2004, the Hungarian private pillar paid a real interest rate of zero percent if one does not neglect the operation costs proportional to contributions and assets as is the case in Hungary.)

3. There are very few countries with private life annuities, especially those that pay indexed unisex annuities. (In Hungary, the period of 1998-2004 was not long enough to plan such an institution!)

4. Although the contributions to the private pillar do not constitute personal income, they still do not flow into the public treasury or government budget. (In 2005, the EU authorized the Hungarian government that it can deduct from its budget deficit a declining portion of these lost revenues from its official budget, starting with $100 \%$ of the in 2005 and ending with $20 \%$ in 2009.)

\section{LESSONS FROM GENERATIONAL ACCOUNTING}

A basic complaint of the opponents of public systems is that these systems achieve strong and unsustainable intergenerational redistribution. In fact, Auerbach et al. (1994) developed the Generational Accounts to measure the extent of intergenerational redistribution. The core of the method is as follows: pick up a base year (denote it o) and by fixing the prevailing distributional trends and projecting productivity trends, determine the net present value of transfers for each generation already born or yet to be born. The long-term government budget constraint can necessitate a uniform correction for the net contributions and net present values of all future generations. Using this method, it can be shown that in most countries the correction factor is much greater than 1, i.e., future generations will have to pay much higher detrended lifetime net contributions than the just born generation pays. In general, the net contributions comprise all social expenditures but it is possible to confine the examination to pensions giving particular emphasis to the gradual transformation of the Hungarian pension system started in 1997. 
In the present subsection we display such calculations by Gál and Tarcali (2003) concerning the Hungarian pension system, revising an earlier calculation by Gál et al. (2001). We emphasize the following specifics of these works.

The generational accounting does not give a forecast but computes the long-run consequences of the maintenance of the present trends. It only applies forecasts at a single point, namely forecasting demographic processes which are more or less independent of the economy. There is no alternative, since according to conventional wisdom, it is aging that is the main culprit responsible for intercohort tensions.

Recapitulating information of earlier sections on the Hungarian pension reform, I mention the following facts: 1) the full benefit age is increasing from 55 and 60 years to a uniform 62 years between 1997 and 2009; 2) continued pensions are raised by combined price-wage indexation from 2000; 3) progressivity is gradually phased out by 2009, 4) from 2013 on, the pension scale becomes linear; 5) pensions will be taxable beginning 2013; and last but not least, 6) the second pillar was introduced in 1998.

To get a benchmark, we set out from a base run, assuming that no trend except for demography changes. In the base runs, using internationally accepted parameter values, we calculated the annual growth rate of productivity (1.5\%); the discount rate (5\%); and the real interest rate (4\%). We also made sensitivity calculations.

Table 2 recapitulates the summary table of Gál and Tarcali (2003), where the reform steps are evaluated separately and in combination.

Table 2.

\section{Hungarian pension accounts, thousand dollars, 2000}

\begin{tabular}{|l|l|l|l|l|l|l|l|}
\hline Type & $\begin{array}{l}\text { Bench- } \\
\text { mark }\end{array}$ & $\begin{array}{l}\text { Combined } \\
\text { indexation }\end{array}$ & $\begin{array}{l}\text { Higher } \\
\text { full } \\
\text { benefit } \\
\text { retirement } \\
\text { age }\end{array}$ & $\begin{array}{l}\text { Phasing- } \\
\text { out } \\
\text { pro- } \\
\text { gression }\end{array}$ & $\begin{array}{l}\text { Linear } \\
\text { pension } \\
\text { scale }\end{array}$ & $\begin{array}{l}\text { Partial } \\
\text { pre- } \\
\text { funding }\end{array}$ & Total \\
\hline Future & 13.6 & 7.2 & 7.8 & 14.8 & 12.0 & 10.6 & 0.6 \\
\hline Newborn & 1.2 & 3.0 & 2.1 & 1.1 & 1.6 & 1.2 & 3.2 \\
\hline
\end{tabular}

Source: Gál and Tarcali (2003), Table 1.

We omitted the paths of older cohorts, since their accounts do not contain the net contributions already paid in, thus their use is limited.

In our benchmark we considered the situation prevailing at the beginning of 1998, excluding the increase in full benefit age, and taking into account the situation of 2000 . 
What our results show in this scenario is that a newborn has to contribute 1200 dollars, while a typical member of a future cohort must contribute about 13,600 dollars. (Be aware that the real dollar-forint exchange rate has recently weakened substantially.)

Taken in itself, the first and most important step is the introduction of combined pricewage indexation. This measure alone increases the burden of a newborn by a factor of 2.5 but halves that of future cohorts. The second step is the completion of raise of full benefit age. This measure almost doubles the burden of the newborn, while reducing that of the future cohorts by $43 \%$. The phasing out of progressivity and the introduction of a linear pension scale are important but not decisive steps. We thus arrive at a measure considered as the reform by many experts and nonexperts: the partial prefunding and privatization of the pension system. In itself, this measure has a definitely much more modest impact than that of the combined indexation: the newborn's burden remains, while the burden of future generations eases by $22 \%$.

Finally let us consider the full impact of the reform. The burden of the newborn is almost tripled, while that of the future cohorts almost disappears. Of course, these are only numbers and how uncertain they are can be seen from a comparison with the earlier version (Gál et al., 2001). The moderate proponents of prefunding and privatization may argue that without prefunding and privatization the population would not have accepted the 'rationalization' of the public system, namely the introduction of combined indexation and the raising of the full benefit age. The radical proponents of privatization of the SS system regret that the Hungarian government was not able to implement a more radical reform, leaving greater room for the second pillar and replacing wage indexation by price indexation.

Turning from the plans to reality, a recent reassessment of the Hungarian pension reform (Orbán and Palotai, 2005) confirmed that the hopes of the reformers have not come true. On the one hand, the governments have sacrificed the financial balance of the first pillar at the altar of parliamentary elections. On the other hand, the substandard results of the private pension funds would probably diminish the total benefits of the joiners with respect to the non-joiners until 2050.

\section{COMPARISONS}

In this section we compare the US and the Hungarian SS systems and their reforms, recapitulating our story told so far. To make the comparison more transparent, we index the similarities and the differences between the old systems (A and B) and the reforms ( $\mathrm{C}$ and D). Table 3 comprises the keywords. 


\section{Comparison of the SSS of the two countries}

\begin{tabular}{|c|c|c|}
\hline \multirow[t]{2}{*}{ SIMILARITIES } & DIFFERENCES & \\
\hline & US & Hungary \\
\hline \multicolumn{3}{|l|}{ PREREFORM } \\
\hline A1. Universal & B1. Rich country & Middle-income country \\
\hline $\begin{array}{l}\text { A2. Redistributive: } \\
\text { progressive }\end{array}$ & B2. Huge trust fund & No trust fund \\
\hline A3. Low savings & B3. Popular system & Unpopular system \\
\hline \multirow[t]{4}{*}{ A4. Unsustainable } & B4. Small hidden economy & Large hidden economy \\
\hline & $\begin{array}{l}\text { B5. Middle-sized replacement } \\
\text { rate }\end{array}$ & High replacement rate \\
\hline & B6. Price-indexed benefits & Wage-indexed benefits \\
\hline & B7. Large "voluntary" pillar & Small voluntary pillar \\
\hline \multicolumn{3}{|l|}{ REFORM } \\
\hline C1. Raising the retirement age & $\begin{array}{l}\text { D1. Pillar } 1 \text { remains } \\
\text { progressive }\end{array}$ & Pillar 1 becomes proportional \\
\hline $\begin{array}{l}\text { C2. Reduction of the benefit- } \\
\text { contribution ratio from } \\
\text { Pillar } 1\end{array}$ & $\begin{array}{l}\text { D2. Price rather than wage- } \\
\text { valorization of AIME }\end{array}$ & $\begin{array}{l}\text { Wage-price rather than } \\
\text { wage-indexation of benefits }\end{array}$ \\
\hline $\mathrm{C}_{3}$. Partial privatization & $\begin{array}{l}\text { D3. Limited contribution to } \\
\text { Pillar } 2\end{array}$ & $\begin{array}{l}\text { "Unlimited" contribution to } \\
\text { Pillar } 2\end{array}$ \\
\hline C4. Carve-out & $\begin{array}{l}\text { D4. Full recognition of past } \\
\text { contributions }\end{array}$ & $\begin{array}{l}\text { Partial recognition of past } \\
\text { contributions }\end{array}$ \\
\hline C5. Medium-size Pillar 2 & $\begin{array}{l}\text { D5. Pillar } 2 \text { has weak } \\
\text { guarantees }\end{array}$ & Pillar 2 has no guarantees \\
\hline $\begin{array}{l}\text { C6. Voluntary for workers } \\
\text { already in the system }\end{array}$ & $\begin{array}{l}\text { D6. Pillar } 2 \text { excludes } \\
\text { disability benefits }\end{array}$ & $\begin{array}{l}\text { Pillar } 2 \text { includes optional } \\
\text { disability benefits }\end{array}$ \\
\hline $\begin{array}{l}\text { C7. Pillar } 2 \text { includes survival } \\
\text { benefits only after retirement }\end{array}$ & $\begin{array}{l}\text { D7. Pillar } 2 \text { pays minimal life } \\
\text { annuity }\end{array}$ & $\begin{array}{l}\text { Pillar } 2 \text { pays a normal and } \\
\text { indexed life annuity }\end{array}$ \\
\hline C8. Deficit financing & $\begin{array}{l}\text { D8. The mixed system is also } \\
\text { optional for beginners }\end{array}$ & $\begin{array}{l}\text { The mixed system is } \\
\text { mandatory for beginners }\end{array}$ \\
\hline
\end{tabular}

Before the reform, both countries had universal systems, where the current workers paid the benefits of the current pensioners (A1). Both countries had progressive systems, where on a monthly basis, the more one contributed, the lower was the ratio of the lifetime benefits 
to the lifetime contributions (A2). A large part of the population had no significant source of old-age income other than the SS benefit (A3). In the long run, both systems were, or are, unsustainable (A4).

The reforms have increased the full benefit age $(\mathrm{C} 1)$. The benefit-contribution ratio in the reformed SS system is planned to diminish significantly with respect to the prereform system (C2). The reformed mandatory system is divided into two parts: a part of the total individual contribution is directed into a private account, called Pillar 2, to be invested in the stock market or government bonds $\left(\mathrm{C}_{3}\right)$, while the remaining part flows into the reformed SS system, called Pillar $1\left(\mathrm{C}_{4}\right)$. Per worker contribution to Pillar 2 is about $1 / 4-1 / 3$ of the total contribution $\left(\mathrm{C}_{5}\right)$. In both reforms, the participation in the mixed system is optional for workers already employed at the start of the reform (C6). Both reforms limit the survivor insurance to the postretirement stage $\left(\mathrm{C}_{7}\right)$. Because the redirected contributions are diverted from the source of the SS benefits, the resulting deficit is financed from general revenues during the long transition period (C8).

Of course, there are important differences between the US and the Hungarian prereform systems and their reforms as well. In the prereformed systems the per capita GDP in the US is about three times that of Hungary at purchasing parity prices (B1). There is a huge SS trust fund in the US, while there is no trust fund in Hungary (B2). The unreformed system is quite popular in the US population, while it was quite unpopular in Hungary (B3). Despite illegal immigration, the hidden economy plays a much smaller role in the US than in Hungary (B4). The average replacement rate (the ratio of the average net SS benefit to the average net wage) in the US is much lower than in Hungary (B5). As is usual in most of the developed countries, in the US, every year the SS benefits increase according to prices; while in Hungary, it increased according to (falling real) wages (B6). In the US, already half the population contributes to semivoluntary-semimandatory pension funds (employer's plans, 401(k), etc., see Poterba, 2003), while in Hungary, this sector is still negligible but genuinely voluntary and enjoys relatively larger significant tax relief than its US counterpart (B7). It is a telling sign that the promarket proponents of the private system are not upset by this perverse redistribution from the poor to the rich!

Turning to the differences in the reform (plan)s, the American Pillar 1 is planned to remain progressive, while the Hungarian one is transformed into a proportional one (D1). The reduction of the benefit-contribution ratio in the SS system is planned to be radical in the US, but moderate in Hungary (D2). In the US, the contributions to Pillar 2 are planned to have a ceiling of $\$ 1000$ per year, corresponding to $28 \%$ of the earning ceiling to SS contributions ( $\$ 25,000$ vs. $\$ 90,000$ ); in Hungary, there is a common ceiling for both pillars, amounting to three times the average gross wage (D3). The reformed US system will fully recognize the rights earned in the old system, while the Hungarian one recognizes only those 
rights which were gained in the predecessor of the new Pillar 1, namely about $75 \%$ of the total (D4). Partial recognition was currently proposed by Smetters and Waliser (2004) but with a tight age limit. The US combined system is planned to be progressive, while the public and private Hungarian benefits are proportional to contributions (D5). Logically, the US reform plans to leave disability insurance fully with the SS, while the Hungarian system "included" the corresponding part into Pillar 2 (D6). (The quotation marks refer to the perverse solution, that after becoming disabled, any Hungarian worker can return to the traditional system.) The US reform requires only a minimal level of annuitization, while the Hungarian law correctly insists on a normal one (D7). Due to the low ceiling of the former, and the high ceiling of the latter, this difference is unimportant. Finally, in the US, participation in the mixed system remains optional, while in Hungary it is mandatory for later starters.

\section{CONCLUSIONS}

At the end of the paper, we draw four conclusions.

1. The partial privatization of a mature and universal public system is possible and judging by the share of voluntary joiners, can be quite popular. In the age of our computerized world, even small firms can direct the monthly private contributions of their workers to various funds and the well-developed pension funds are able to invest these relatively small contributions efficiently.

2. The downsizing of the benefit of the remaining public pillar (the parametric reform) is also feasible and helps the transition. But the British experience demonstrates that if it is excessive, then such a policy creates tremendous tensions and leads to the spread of means-tested assistance, undermining voluntary private savings.

3. The partial privatization of the SS system weakens the insurance provided by the system in all fields, diminishing the life-annuitized part of the benefit and increasing the risks associated with disability and survivorship.

4. Partial privatization is possible but it is not worthwhile, especially not worthwhile in a country like the US, where the richer half of the workers already has significant capital accumulated in the "voluntary" pillar. 


\section{REFERENCES}

AARON, H. AND REISCHAUER, R. (2001): Countdown to Reform: The Great Social Security Debate, New York, Century Foundation Press.

AuERBACH, A. J., GoKHAle, J. AND KotlikofF, L. (1994): "Generational Accounting: A Meaningful Way to Evaluate Fiscal Policy", J ournal of Economic Perspectives 8, Winter, 73-94.

AuguszTinovics, M. (1999): "Pension Systems and Reforms - Britain, Hungary, Italy, Poland, Sweden", European J ournal of Social Security 1, 351-382.

AuguszTinovics, M., GÁL, R. I., Matits, Á., Máté, L., Simonovits, A., STAHL, J. (2002): "The Hungarian Pension System before and after the 1998 Reform", Fultz eds. 25-93.

Augusztinovics, M. And MARTOS, B. (1996): "Pension Reform: Calculations and Conclusions", Acta Oeconomica 48, 119-160.

Bokros, L. AND DETHIER J. J. eds. (1998): Public Finance Reform during the Transition: The Experience of Hungary, Washington, D.C, World Bank.

DiAmond, P. (2004): "Social Security", American Economic Review 94, 1-24.

DiAMOND, P.-ORSZAG, M. (2004): Saving Social Security: A Balanced Approach. Washington, D.C. , Brookings Institution Press.

DiAMOND, P.-ORSZAG, M. (2005): "Saving Social Security", J ournal of Economic Perspectives, 19:2, 11-32.

FELdSTEIn, M. (2005a): "Social Insurance", American Economic Review, 95, 1-24.

FELDSTEIN, M. (2005b): "Structural Reform of Social Security", J ournal of Economic Perspectives, 19:2, 33-55.

FELdSTEIn, M. AND SAMwick, A. (2002): "Potential Paths of Social Security Reform", Poterba ed. (2002), 181-224.

FELDSTEIN, M. AND SIEBERT, H. eds. (2002): Social Security Reforms in Europe, Chicago, IL: Chicago University Press.

Fultz, E. eds. (2002): Pension Reform in Central and Eastern Europe, Vol. 1-2, Geneva, ILO.

GÁL, R. I., Simonovits, A. AND TARCALI G. (2001): "Pension Reform and Generational Accounts", World Bank Social Protection Discussion Paper 0127.

GÁL, R. I. AND TARCALI, G. (2003): "Pension Reform and Intergenerational Redistribution in Hungary", The (J apanese) Economic Review, 54, 237-247.

GiLl, S. I., PACKARD, T AND Yermo, J. (2005): Keeping the Promise of Social Security in Latin America, Palo Alto, Stanford UP and Washington, World Bank.

Holzmann, R. AND STiglitz, R., eds. (2001): New Ideas about Old-Age Security: Toward Sustainable Pension Systems in the 21st Century. Washington, D.C., World Bank.

KoTLIKOFF, L. (1997): "Privatization of Social Security: How it Works and Why it Matters?" Poterba, J . ed., 1-30.

Murthi, M., Orszag, J. M. AND ORsZAG, P. R. (2001): "The Charge Ratio on Individual Accounts: Lessons from the UK Experience", Holzmann and Stiglitz, eds., 308-335.

MÜLLER, K. (1999): The Political Economy of Pension Reform in Central-Eastern Europe, Cheltenham, UK, Edward Elgar.

MÜLLER, K., RYLL, A. AND WAGENER, H. J. EDS. (1999): Transformation of Social Security: Pensions in Central-Eastern Europe, Heidelberg, Physica. 
ORBÁn, G. AND PALOTAI, D. (2005): "The Sustainability of the Hungarian Pension System: A Reasessment", Budapest, Hungarian National Bank.

ORSZAG, P. AND STiglitZ, J. E. (2001): Rethinking Pension Reform: Ten Myths about Social Security Systems, HOLZMANN AND STIGLITZ, eds, Washington, The World Bank. 17-56.

PALACIOS, R. AND Rocha, R. (1998): The Hungarian Pension System in Transition, BOKROS AND DETHIER (eds.) 177-216.

PoterbA, J., ed. (1997): Tax Policy and the Economy 10, Cambridge, MA, MIT Press.

Poterba, J., ed. (2002): Tax Policy and the Economy 16, Cambridge, MA, MIT Press.

PoterbA, J. (2003): "Employer Stock and 401(k) Plan", American Economic Review, Papers and Proceedings 99, 398-404.

Pozen, R., Scheiber, S.J. AND SHOven, J. (2004): "Improving the Social Security's Progressivity and Solvability", American Economic Review, Papers and Proceedings 94, 187-191.

PRESIDENT'S COMMISSION TO STRENGTHEN SOCIAL SECURITY (2002): www.csss.gov/report/Final_report.pdf.

Rocha, R. AND ViTTAS, D. (2002): "The Hungarian Pension Reform: A Preliminary Assessment", FELDSTEIN AND SIEBERT, eds. 365-400.

Simonovits, A. (2001): "Partial Privatization of a Pension System: Lessons from Hungary", International J ournal of Development 12, 519-529.

Simonovits, A. (2003): Modeling Pension Systems, Oxford, Palgrave Macmillan.

SMETTERS, K. AND WALISER, J. W. (2004): "Opting out of the Social Security", J ournal of Public Economics 88, 1295-1306.

VITTAS, D. (1997): "Designing Pension Reform Programs: Lessons from Recent Experience", Working Paper Series, University of Ljubljana.

WORLD BANK POLICY RESEARCH REPORT (1994): Averting the Old Age Crisis, Oxford, Oxford University Press. 


\section{Discussion Papers/Mühelytanulmányok published since 1999}

2004

Attila HAVAS: Assessing the Impact of Framework Programmes in a System in Transition. MT-DP. 2004/1

Max GILLMAN-Michal KEJAK: Inflation and Balanced-Path Growth with Alternative Payment Mechanisms. MT-DP. 2004/2

L. AMBRUS-LAKATOS-B. VILÁGI-J. VINCZE: Deviations from interest rate parity in small open economies: a quantitative-theoretical investigation. MT-DP. 2004/3

HALPERN László és szerzőtársai: A minimálbér költségvetési hatásai. MT-DP. 2004/4

FALUVÉGI Albert: A társadalmi-gazdasági jellemzők területi alakulása és várható hatásai az átmenet időszakában. MT-DP. 2004/5

Mária CSANÁDI: Budget constraints in party-states nested in power relations: the key to different paths of transformation. MT-DP. 2004/6

Mária CSANÁDI: A comparative model of party-states: the structural reasons behind similarities and differences in self-reproduction, reforms and transformation. MT-DP. 2004/7

KARSAI Judit: Helyettesítheti-e az állam a magántőke-befektetőket? Az állam szerepe a magántőke-piacon. MT-DP. 2004/8

Judit KARSAI: Can the state replace private capital investors? Public financing of venture capital in Hungary. MT-DP. 2004/9

Mária CSANÁDI: Do party-states transform by learning? The structural background of the different transformation paths in view of the Romanian, Hungarian and Chinese cases. MT-DP. 2004/10

István CZAJLIK - János VINCZE: Corporate law and corporate governance. The Hungarian experience. MT-DP. 2004/11

L. HALPERN et al: Firms' Price Markups and Returns to Scale in Imperfect Markets:

Bulgaria and Hungary. MT-DP. 2004/12

Norbert MAIER: Explaining Corruption: A Common Agency Approach. MT-DP. 2004/13

Gergely CSORBA Screening Contracts in the Presence of Positive Net-work Effects. MT-DP. 2004/14

K. BOGNÁR - L. SMITH We Can't Argue Forever. MT-DP. 2004/15

JUHÁSZ A. - SERES A. - STAUDER M A kereskedelmi koncentráció módszertana. MT-DP. 2004/16

Júlia LENDVAI Inflation Inertia and Monetary Policy Shocks.MT-DP. 2004/17

A. FREDERIKSEN -E. TAKÁTS Optimal incentive mix of performance pay and efficiency wage. MT-DP. 2004/18

Péter KONDOR The more we know, the less we agree: public announce-ments and higherorder expectations MT-DP. 2004/19

B. BARANYI - I. BALCSÓK Határ menti együttmüködés és a foglalkoztatás - keletmagyarországi helyzetkép. MT-DP. 2004/20

L.Á. KÓCZY - L. LAUWERS The minimal dominant set is a non-empty core-extension. MTDP. 2004/21

Miklós KOREN The law of two prices: trade costs and relative price variability. MT-DP. 2004/22

A. AMBRUS - R. ARGENZIANO Network Markets and Consumer Coordination. MT-DP. 2004/23

LÓCSEI Hajnalka A vidéki városi agglomerációk fejlődési pályája. MT-DP. 2004/24

J.D.BROWN - J.S. EARLE - Á. TELEGDY Does Privatization Raise Productivity?. MT-DP. 2004/25

HÂRS Ágnes A magyar munkaerő-migráció regionális sajátosságairól. MT-DP. 2004/26 
GÁCS János A lisszaboni folyamat: rejtélyek, elméleti problémák és gyakorlati nehézségek. MT-DP. 2005/1

PÉTERI Gábor Igazodás a piacgazdaság szabályaihoz és megfelelés a helyi elvárásoknak - A városi polgármesterek értékrendje. 2004. MT-DP. 2005/2

SZALAI Ákos Adóverseny az iparüzési adóban - Az 5000 fö fölötti települések adópolitikája a 2000-es években MT-DP. 2005/3

Gábor BÉKÉS - Balázs MURAKÖZY Firm behaviour and public infrastructure: The Case of Hungary. MT-DP. 2005/4

Gusztav NEMES The politics of rural development in Europe. MT-DP. 2005/5

Gusztav NEMES Integrated rural development - the concept and its operation. MT-DP. 2005/6

Anikó JUHÁSZ - Antal SERES - Mátra STAUDER A kereskedelmi koncentráció tendenciái. MT-DP. 2005/7

Hajnalka TARJÁNI Estimating some labour market implications of skill biased technology change and nt he sin Hungary. MT-DP. 2005/8

L. HALPERN - M.KOREN.- Á. SZEIDL Import and Productivity. MT-DP. 2005/9

Szabolcs LŐRINCZ Persistence Effects in a Dynamic Discrete Choice Model - Application to Low-End Computer Servers. MT-DP. 2005/10

Péter VIDA A Detail-free Mediator and the 3 Player Case. MT-DP. 2005/11

László Á. KÓCZY The Core Can Be Accessed with a Bounded Number of Blocks. MT-DP. 2005/12

Viktória KOCSIS Network Asymmetries and Access Pricing in Cellular Telecommunications. MT-DP. 2005/13

István KÓNYA Economic Development, Exchange Rates, and the Structure of Trade MT-DP. 2005/14

Gábor G. SZABÓ - Krisztina BÁRDOS: Vertical Coordination by Contracts in Agribusiness: An Empirical Research nt he Hungarian Dairy Sector. MT-DP. 2005/15

Attila AMBRUS: Theories of coalitional rationality. MT-DP. 2005/16

Jin-Chuan DUAN - András FÜLÖP: Estimating the Structural Credit Risk Model When

Equity Prices Are Contaminated by Trading Noises. MT-DP. 2005/17

Lawrence UREN - Gábor VIRÁG: Wage Inequality in a Burdett-Mortensen World. MT-DP. 2005/18

Berthold HERRENDORF - Ákos VALENTINYI: Which Sectors Make the Poor Countries so Unproductive?. MT-DP. 2005/19

János GÁCS: The macroeconomic conditions of EU-inspired employment policies. MT-DP. 2005/20

Katalin CSATÓ: Egy fiziokrata: Paul-Pierre Le Mercier de la Rivière. MT-DP. 2005/21

2006

Krisztina MOLNÁR - Sergio SANTORO: Optimal Monetary Policy When Agents Are Learning. MT-DP. 2006/1

Disscussion Papers are available at the website of Institute of Economics Hungarian Academy of Siences: http://econ.core.hu

A kötetek letölthetők az MTA Közgazdaságtudományi Intézet honlapjáról:

http://econ.core.hu 